\title{
Managers' Beliefs about Measures to Retain Senior Workforce
}

I Reidar J. Mykletun'

Professor, Norwegian School of Hotel Management, University of Stavanger, Norway

I Trude Furunes

Associate professor, Norwegian School of Hotel Management, University of Stavanger, Norway

I Per Erik Solem

Professor, Senior Researcher, Norwegian Social Research, Norway

\begin{abstract}
This paper aims to describe and explain the beliefs of public sector managers regarding measures to promote active ageing within organizations and how these beliefs can relate to their own attitudes, age, gender, organizational roles, and structures. Data were collected by mailed questionnaires from 672 managers on operative and administrative levels in the Norwegian municipal and health sectors. It was found that managers believe in the usefulness of at least seven different measures, identified by factor analyses. Sum scores were calculated from the factors, and five of them showed sufficient reliability. Ranked according to their mean values, the factor-based sum scores were I) reducing working hours, increasing the number of holidays, and offering flexible part-time schedules without a reduction in wages; 2) reducing workload and demands; 3) increasing wages, pensions, and bonuses; 4) increasing esteem, learning, and job enrichment for the senior workers; and 5) repositioning the workers to other, less demanding parts of the organization. In multiple regression analyses, these sum scores were found to be influenced mainly by the managers' individual attributes, like age, gender, own retirement plans, beliefs, and attitudes. Organizational and structural factors seemed less important. The findings are discussed within three schools of thought: the 'Human Relations Model,' the 'Market Model,' and the 'Age Management Model.' A fourth 'school,' the 'Laissez-faire Model,' is indicated by the $26 \%$ of managers who claimed no responsibility for the age management issues.
\end{abstract}

\section{KEY WORDS}

Age management / extending older workers' careers / ageing and work / public sector management / older workers / manager attitudes / managers' beliefs

\section{Introduction}

\section{The backdrop for the study}

ike most of today's Western societies, Norway is facing changing demographics. Increasing immigration, especially after year 2004; longer lifetime expectancies; and lower fertility rates have led to estimates that for the years 2007-2030 the age group

\footnotetext{
${ }^{1}$ Norwegian School of Hotel Management, University of Stavanger, N-4036 Stavanger, Norway.

E-mail: reidar.j.mykletun@uis.no
} 
$25-49$ will increase by $13 \%$, the age group $50-64$ by $18 \%$, the age group $65-74$ by $72 \%$, the age group $75-79$ by $71 \%$, and the age group $80+$ by $65 \%$ (Furuberg et al. 2008). Several consequences will follow on societal, employment, and individual levels. For society, there will be an increase in pension expenses and, in future years, the cost will be difficult to handle because the ratio of retired individuals per active worker is estimated to decrease to $1 / 2.6$. The costs will be passed on to work organizations and the individual workers. There will also be an increasing lack of labor (Hoviskeland et al. 2001), and the trend is aggravated by any decline in retirement ages.

The mandatory retirement age in Norway is 70 years, and retirement is optional from age 62. Exit via disability pensions is possible up to 67 years and peaks at the age of 63 years. Health problems account for approximately $60 \%$ of the disability pensioning cases (Mykletun et al. 2006). Early exits may be caused by the individual worker's dream of an improved quality of life (Featherstone and Wernick 1995). Still, 64\% of the workforce aged 55-64 is active in working life, which is among the highest worldwide. A large proportion of female workforce also in older age groups contributes to this. Moreover, older workers have been retained by employers, partly due to shortage of workforce. Unemployment rates have varied between 2 and $4 \%$ since the turn of the century, and even through the economical recession it was kept below 5\%. This favorable situation has been explained as “... a combination of luck, skill and caution” (NOU 2011, p. 240). The luck lies in the oil resources, while the oil industry revenues and the financial institutions were managed with skill and caution, using only $4 \%$ of the government revenues from the petrol sector in the domestic economy (see Solem 2012 for a detailed explanation). Currently, there is a shortage of workforce and immigration of skilled labor, hence nurses and engineers are welcomed.

However, the field is more complex since one can still observe the myths and their age discriminatory practices emerging from 'The Decremental Theory of Aging.' Using this rationality, the emphasis is on how the workforce's capabilities successively decline over the years due to the biological toll taken by the ageing of the organism, e.g., physical strength, the senses, attention span, intellectual functions, and reaction speed (Chan et al. 2000; Laflamme and Menkel 1995). As the individual capacities decline, the worker should be laid off as useless when regarded from the employer's financial perspectives. Maintenance in the sense of competence development or diversification of work demands does not pay off for the company, according to this view. As stated by DeBeauvoir (1976), in our time of rapid change, machines are short-lived, humans should not serve too long, and everyone aged 55 or older should be discarded as being of no value for working life. The concern has grown regarding the possibility that disability pensions could cover some practices along these lines.

In contrast to this, it has become a strong imperative for society and working life to prevent early exits and extend working life careers to reduce pension costs and preserve competence and sufficient access to manpower. As estimated by Furuberg et al. (2008), if $60 \%$ of those aged $62-67$ years in Norway work part-time (50\% positions) for 2 years, close to 50,000 man-years would become available for the labor market. The Norwegian government, the main employers' associations, and the main workers' associations have developed a three-partite program on a more inclusive working life named the 'IA Agreement.' Work organizations subscribing this agreement should strive to reduce sick leaves, include disabled persons in their workforce, and employ older workers and extend their careers. 
For the employers and their managers at all levels, the urge to find ways of dealing with career extensions is rising from the discovery of shrinking access to competent workers and growth in immediate expenditures related to an increasing number of retirees and disabled workers. It has also been argued that a good job has its own value as it adds to human growth and development in later years as well; however, this of course depends on several factors such as the individual's capacity, the work content and environment, the family of the worker, and a broader social context.

Previous research has demonstrated that the municipal workforce, who encompasses a large share of the public sector workforce, at an average prefers to retire at 60 , if allowed. Moreover, the managers within this sector expressed a significantly stronger urge to retire at the earliest possible date than their rank-and-file workforce (Mykletun et al. 2000), probably reflecting a strong work pressure, role conflicts, and ambiguities for managers related to recent re-structuring and increasing work demands of these workplaces (Pettersen 2001). An increase in complaints about health problems and reduced work ability after the age of 45 were observed for both the workforce and managers alike (Mykletun et al. 2000), as was also reported for the Finish municipality workforce (Tuomi et al. 1999).

Age $45+$ is notably in the lower range concerning use of the term 'elderly' or 'senior' worker (Ilmarinen 2001; Kilbom et al. 1997; Tikkanen 1999), although some use the higher age limit of 55+ (Stern and Miklos 1995) when trying to define the senior workforce. Norwegian managers in 2011 define older workers as about 55.5 years of age and above; however, this limit has changed from 52 years of age in 2004 (Dalen 2011a). Workforce themselves report 57.7 years of age as the limit to become an older worker (Dalen 2011b). For the purpose of the present paper, age 55+ is used to denote older workers.

In sum, one should expect that the art of retaining elderly workers in the public sector can be a challenge, and that managers and employers would be looking for actual and practical ways to achieve this valued goal. This paper researches the problem of the search for possible ways to extend senior workforce careers in the public sector in Norway. Also, the questions are posed with regard to how such measures can be related to selected structural, organizational, and individual factors. Structural factors include type of institution (county level, municipality level, public health), while organizational factors encompass managers' roles within the organization, control span, and responsibilities. Managers' attitudes and beliefs about age management are included, as are the managers' own senior career plans and biographical data.

\section{Concepts and theoretical considerations}

Measures to extend senior workforce careers are not clarified theoretically or empirically, although they could be referred to as the emerging realm of 'age management' (Furunes and Mykletun 2005; Ilmarinen 2001, 2002). The term age management has been launched to denote management strategies and techniques with a special focus on age-related issues at the workplace. However, the term still lacks a relationship to established theories and concepts within theories of workplace management, leadership, and work environment issues. One way of anchoring the term could be within the recent developments in workplace diversity management (Agars and Kotke 2004; 
Hays-Thomas 2004; Johnston and Packer 1987), which may be seen as the broader framework for analyzing these challenges. The construct diversity is used here to refer to inter-individual differences among workers that are likely to affect how they are appreciated, their work performance and satisfaction, and their late careers within an organization. Managing diversity refers to the purposeful use of processes and strategies that can turn inter-individual differences into assets rather than liabilities for the work organization. These strategies and processes aim to improve interactions among different people and make this diversity a source of creativity, complementarities, and effectiveness rather than tension, conflicts, and lacks of effectiveness and satisfaction (Hays-Thomas 2004). As will be argued below, when applying these strategies and processes within the age management area, a wide range of challenges will be elicited, including the uneven distribution of demands, expectations, workloads and work content, rewards and facilitation. Managers would probably benefit from establishing relevant strategies, and employers need to recognize the challenge by allocating budgets to allow for possible expenses. Embedded in this, the managers need to perceive a reasonable room to maneuver or latitude to act on age management issues and make age management materialize (Furunes et al. 2011).

Because one of the main challenges within workplace age management seems to be the prevention of early retirement, it is likely that the research within this field should also lean on knowledge gained within the area of workforce retention management (Bell 2003; Butler and Waldroop 2001; Forsberg 2001; Friedman et al. 1998). The term workforce retention refers to reducing the leak of competence caused by members of the workforce leaving the organization, not dismissed due to misconduct. Workforce retention management refers to the purposeful development and use of processes and strategies that might stop this leak. Within the field of Human Resource Management (HRM), it is recognized that employee retention management is of increasing value for corporate strategy: 'With employees quickly becoming business' greatest asset, employee retention must become a company's highest priority. It's not enough to hope employees will stay. HR must give them the reasons to stay' (Flynn 1994, p. 49).

The issue is accelerated by the tighter labor markets that have shifted power from employers to employees, leading to challenges for employers in finding new ways of managing employees, and where the most important and pressing need is the challenge of retention (Cappelli 2000). Significantly, the development from a personnel management strategy to an HRM approach shows this stronger emphasis toward a focus on the 'human resources' within an organization (Torrington and Hall 1998). A similar approach might be useful when analyzing an early exit and retirement from work. The senior workforce is not expected to show a high inter-company turnover; however, retirement could be the alternative that pulls and pushes workers out of participation in working life. For instance, McFillen et al. (1986) concluded from their analysis that job satisfaction - particularly related to work and advancement - strongly affects commitment, which in turn influences intentions to stay or leave. Job dissatisfaction and interrole conflicts are known to accelerate withdrawal cognitions and searches for alternatives (Hom and Kinicki 2001). Low performers are more likely to leave their jobs compared with high performers (Griffeth et al. 2000; Sturman and Trevor 2001). Quality of supervision will probably be related to workforce retention and supervisors viewed as being inconsiderate of employees' needs cause higher withdrawals from jobs (Wasmuth and Davis 1983). Ineffective communication and general poor employment practices are also 
seen as major causes of labor turnover (Price 1994; Rowley and Purcell 2001). Similarly, unpleasant working conditions, stress and work group cohesion, which often demand intense collaboration, or repetitive and unchallenging tasks counteract workforce retention (Rowley and Purcell 2001). Thus, satisfaction, commitment, and work content and organization seem to be useful concepts when striving to retain a workforce.

At least four different schools of thought might inspire the selection and development of measures to extend senior careers. We have conceived of them as 1) the 'Laissezfaire approach'; 2) the 'Market Model'; 3) the 'Human Relation Model'; and 4) the 'Age Management Model.' These will be briefly outlined below.

One extreme is 'Laissez-faire approach,' i.e., the manager avoiding to care about an issue altogether (Bass 1999). Two varieties of this style are included in the Multidimensional Leadership Questionnaire as developed by Aviolo et al. (1995), namely 'passive laissez-faire' (no intervention) and 'management by exception' (no intervention before badly needed). The concept was first coined by Lewin and Lippit (1938) in their often cited work about autocratic and democratic methods of initiating structures in a small social group. Similar concepts have emerged over time and are shown to be interrelated, for instance isolated, passive, withdrawn, unconcerned, inactive, abdicating, or uninvolved (Edwards and Rode 1986). Laissez-faire leadership shows strong negative correlations to active leadership strategies (Bass 1990). In our study, this should appear as managers claiming to be unaware of the challenges of senior workforce career extension and their own responsibilities in this respect, or lack of initiatives related to the issue.

A second way of thinking could be based on the idea that the relationship between the worker and the organization is a matter of exchange in economical terms, where the worker's time and energy are for sale provided they get the best return (Cappelli 2000; Leopold et al. 2005). We coined it the 'Market Model.' The basic mindset is that the workforce exists for the sake of the organization and its need for manpower and may be managed according to the model of the 'Homo economicus' (Camarer 2002) or incentive model. In this case, the managers' ways of thinking might include manipulating the wages, bonuses, and pension levels to achieve the goals of the organization, e.g., by rewarding the productive older workers with higher wages, bonuses, and pensions for extensions of work careers. As a leadership style, it is to some extent related to the 'transactional' leadership as described by Aviolo et al. (1995). For the individual worker, this could be perceived as an advantageous choice between hours spent at work and increased economical rewards. To our knowledge, these incentive strategies are successfully used in some municipal administrations. In terms of retention management, this approach should be thought of as increasing job satisfaction through higher payments, as well as solving possible economical problems for the individual worker. For instance, bonus systems for prolonging careers past the first option of retirement are now used in some of the Norwegian municipalities (Hilsen and Salomon 2010).

A third approach could emerge from the Human Relation tradition, coined here as the 'Human Relation Model.' Within this framework, it is acknowledged that organizations need people and people need organizations. A mismatch between the two will destroy this relationship because one or both of them would suffer, while the good match should bring human energy into the workplace, giving the individual meaningful and satisfying work (Bolman and Deal 2004). Individual resources have developed through experience throughout a long working life and should be beneficial for the organization, 
provided they are observed, relevant, and used (Brooke 2003; Gould-Williams 2004). A basic assumption might perhaps be that '...it is most helpful to think about human resources as the capabilities and potential that people bring to work organisations to enable organisations to fulfil tasks and to survive into the long term' (Leopold et al. 2005, p. XXIX). Transferred to the area of career extension and of relevance to this research, processes and strategies from this school of thought should include general workplace improvement measures like learning opportunities, esteem and attention, mentoring functions, specialist roles, and broadening the range of tasks and responsibilities as the individual worker reaches his/her senior career, thus motivating for an extended career by developing attractive work content. Also this approach is applied in the Norwegian municipality sector (Hilsen and Salomon 2010) and is a central and effective ingredient in the Vattenfall Age Management Program (Mykletun and Furunes 2011).

The forth approach, the 'Age Management Model,' has several practical and theoretical roots and is today associated with several different connotations. As outlined here, the model departs primarily from the work of Juhani Ilmarinen (2001, 2002). At the outset, this model was inspired by a biological view of human capacities and related to an assessment tool called the Work Ability Index, measuring perceived capacity and health. The initial approach assumed that there is an increasing risk of decline in working capacity and health with increasing age. The loss of working capacity will make the individual feel more exhausted after work, but will in about $70 \%$ of the cases not make the individual unable to perform work up to the retirement age. According to the model, interventions should focus on improving the individual health and physical capacity, on competence maintenance, and workplace reorganization to provide lighter work or shorter working hours for those who need it. As Ilmarinen argues, '...the myth of ageing and productivity will be corrected: productivity is not dependent upon age but on the organisation of work' (Ilmarinen 2002, p. 30), a view that is supported by for instance Taylor and Walker (1998).

The 'Age Management Model' is eclectic, drawing also on the early work-stress traditions of the person-environment fit models. It also integrates workplace ergonomics in its interventions, leading to reorganization of the workplace and allowing seniors to participate at lower intensity levels, either by adding more leisure time and holidays or otherwise reducing workloads or repositioning the workers to less demanding positions at the end of their careers. Also, it argues for learning and development of health, physical, and mental capabilities, which can be seen as influence from a workforce employability approach (Forte and Hansvick 1999). In the Finnish FINN-AGE program, it has been demonstrated that the application of these strategies and processes increases working ability scores and well-being, reduces sick leave, and provides a better quality of life at work and later, when retired. The program has given from a 3 to 20 times return on economical costs to the employer (Ilmarinen 2002). For instance, Norwegian municipality sector applies also parts of this approach by reducing working hours for workers aged 62+ (Hilsen and Salomon 2010), and the shortening of the work week on individual demand has shown to be a central and effective ingredient in the Vattenfall Age Management Program (Mykletun and Furunes 2011).

Moreover, within this framework, research has also shown that not all human capabilities decline with age and some might even improve. The myths about general drawbacks of a senior workforce are not well supported. For instance, Norwegian municipal employees regard their own age-related changes to include an improvement of social, 
moral, and problem-solving capacities over years, but a simultaneous reduction in sensory capacities and quantitative efficiency (Furunes and Mykletun 2011).

The four strategies and related processes outlined above can vary in application between managers and organizations, and these variations will be studied here. Among the predictors, several types of issues/factors might be observed. Different sectors within the public services might also be thought to differ in their experience with and basic thinking about senior workforces. Thus, it is of interest to study a possible effect of the structural level of the organizations, in our case the county level, municipal and public health institutions, upon preference of measures to extend senior workforce careers.

At the organizational level, it could be expected that managers' position levels would be of interest to this issue because the higher positions should include not only access to more power but also a distance to the actual workers, and vice versa for the managers at the operational level. The size of managers' control span (or number of subordinates) should also have an ability to influence their views on the target variables of this study, as a larger control span should not only provide more opportunities for diversification of the person-environment fit but also a longer distance to the workforce. The acknowledged responsibility for age management should also be important, since it could be expected that those in charge should be more updated on challenges and possibilities than those claiming to have no responsibilities.

At the individual level, it could be expected that stereotypes and beliefs would take a certain position in the managers' mindsets, and that their own attitudes would be reflected in the ways they think about the ageing workforces' career developments (Chan et al. 2000; Davies and Metthews 1991; Taylor and Walker 1998). Attitudes, such as the importance of focusing on age management issues, should matter, as should beliefs about how much the organization could affect the outcome of the senior workers' career plans, and whether the workforce in general should tolerate the apparent injustice created by treating workers differently. Also, the perception of what constitutes 'elderly' should be of interest, as it defines in a practical way the limits and the numbers of seniors at the workplace. Moreover, managers' attitudes about their own retirement plans could be influencing their thoughts about others, as could their own age. Finally, gender could be an issue, as female managers can have a different scope and context for their work than their male counterparts.

\section{Methodology}

\section{Study design}

The population of the study was municipal, county, and public health institution managers in organizations being members of the KLP Pension Insurance Company (KLP) in Norway. The study was designed as an anonymous postal survey, and a quantitative approach using a mailed questionnaire was chosen. Informants were selected by random sampling from KLP's list of member organizations, which covers three types of organizations: municipalities or local authorities, county municipalities, and public hospitals. An invitation was sent to a random sample of deputy mayors and chief administrative officers, who either agreed or disagreed to participate in the survey. Questionnaires were also distributed to the managers in their organizations. In total, 1,587 
questionnaires were distributed from which 672 were returned, yielding a response rate of $42.3 \%$.

\section{Method}

A questionnaire containing 29 questions, including several scales, was developed. The questionnaire probed for information on structural-, organizational-, and individuallevel variables. Representing the structural level, information was sought regarding the type of institution, whether it was a municipal, county, or public health institution, all of which constitute the main KLP membership groups. The responses were recoded into dummy variables $(0=$ No, $1=$ Yes $)$ for the analyses.

On the organizational level, management level (top vs. operational level) was included in the 'Position' variable, which was scaled as $1=$ Administrative manager and 2 = Operational middle manager. The sizes of the managers' control spans were measured by the 'Number of subordinates' variable, where responses could be given to one of five ranges scaled as $1=<20 ; 2=20-49 ; 3=50-99 ; 4=100-499$; and $5=500+$. A question probing for information on 'Degree of responsibility for age management actions' was scaled as 1 = No responsibility; 2 = Responsibility delegated to subordinates; $3=$ Coordinating responsibilities; and $4=$ Direct operational responsibility.

The group of questions eliciting information at the individual level was partly on the beliefs and partly on the attitudes of the respondents. The first question searched for beliefs like, 'Employees' attitudes make it hard to redesign tasks to fit senior workers' and was scaled as 1 = Totally disagree; 2 = Partly disagree; 3 = Partly agree; and 4 = Totally agree. This scaling also applied to two questions asking for attitudes: 'I think it is important to work with age management actions,' and 'I think there is too much focus on age management actions.' The second question on beliefs was 'To what extent can the employer prevent early exits?' and was scaled as $1=$ Not at all; 2 = A little; 3 = Somewhat; and $4=$ High. This scaling was also applied to the questions identifying the managers' personal retirement plans, e.g., 'To what extent would you yourself prefer early retirement when reaching 62?' and 'To what extent would you yourself prefer to continue working beyond the age of 62 with reduced workload?' The third question on beliefs was 'At what age do employees become older workers' and was responded to by providing figures. The respondent's own age was given with year of birth, and gender was scaled as $1=$ Male and $2=$ Female.

The concept of 'Measures to extend senior workforce careers' was measured using 20 items representing the theoretical underpinnings discussed in the Introduction, i.e., the 'Market Model,' the 'Human Relation Model,' and the 'Age Management Model.' The 'Laissez-faire Model' was not coined with unique items, but was represented by the response 'Don't know' on the item of responsibilities for senior policies. The items representing the 'Market Model' (incentive model) focused on changing wages, bonuses, and pensions to reward the likelihood of lengthening the career and economically punishing the early exit strategy. The items representing the 'Human Relation Model' searched responses to use job enrichment, learning, and esteem as the major strategies to motivate for delayed retirement. The items representing the 'Age Management Model' focused on questions like reducing work pressure and responsibilities, shortening daily working hours and extending holidays, and repositioning the seniors to achieve easier work tasks 
and load reduction. The details of these items are seen in Table 2 in the Results section. The question asked about the managers' evaluation of the perceived effectiveness of 22 measures to motivate older workers to postpone their retirement. The scaling was $1=$ Not at all; 2 = A little; 3 = Somewhat; and 4 = High.

\section{Procedures}

The respondents were asked by e-mail whether they would participate in the study. For those who agreed, the actual questionnaires were mailed from the KLP Administration Office in Oslo. Enclosed was a letter explaining the purpose of the study and an envelope facilitating an anonymous return of the completed questionnaire to KLP. Slow responders were reminded by e-mails that were sent twice to the entire sample. New respondents were drawn at random from the archive to replace non-responders. The respondents' characteristics regarding age and gender are shown in the Results section. The distribution according to age and gender was judged to reflect the KLP membership profile adequately.

\section{Data analyses}

Data were entered into SPSS for analyses. The 20 items identifying 'Measures to extend senior workforce careers' were analyzed by Explorative factor analysis (Varimax rotation with Kaiser Normalization and applying Principal Component Analysis as the extraction method), resulting in seven factors (Table 2). From these, seven factor-based sum scores were calculated and tested for internal consistencies using alpha coefficients, leaving only five of the sum score variables for the final analyses due to low reliability. The sum score values were divided by the number of items each of them was based upon to make them comparable and easier to interpret in relation to their underlying scales. These mean sum scores were then analyzed by comparing their mean values and confidence intervals by means of the SPSS procedure 'Error bars' and $t$-tests (Figure 1).

The relationships between predictors and factor-based sum scores were analyzed using multiple regression analyses, and standardized beta coefficients are displayed together with their significance levels and explained amount of sum score variance in Table 3. The analyses were performed stepwise against the 15 independent variables described above, covering structural, organizational, and individual aspects. The independent predictor variables concerning structural matters were entered first, the organization-level variables were second, followed by individual variables in steps 3 to 5 .

\section{Results}

The sample consisted of 54\% municipal managers, $16 \%$ county managers, and $30 \%$ managers from public health enterprises and had an equal gender distribution. Except for the county municipality segment, which is overrepresented, the segments were equally sized to the segments in KLP's customer database. Of the sample, $27.5 \%$ were administrative managers, and $72.5 \%$ are operational or middle managers. Furthermore, 
Figure I: Mean values and 95\% confidence intervals for 'measures' sum scores (error bars). The horizontal lines indicate upper and lower confidence interval for each mean sum score. The squares on the vertical lines indicate the mean value. The difference between two variables is significant on a $5 \%$ level when the mean of one variable is outside the range of the confidence interval of the other variable $(n=660)$.

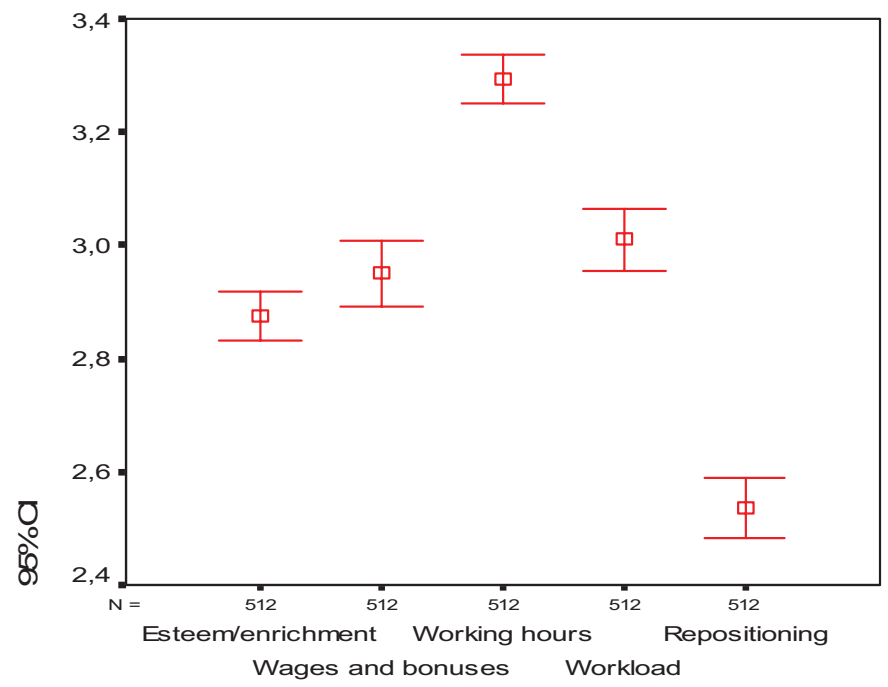

$40 \%$ of the respondents had less than 20 subordinates, $26 \%$ manage $20-49$ subordinates, $17.5 \%$ have $50-99$ subordinates, and $16.5 \%$ had more than 100 subordinates. Ninety-one percent of the organizations represented had entered the IA Agreement. Full responsibility for age management was admitted by $41 \%$ of the managers, while $24 \%$ acknowledged responsibility for coordinating age management, 9\% had delegated age management responsibilities to a subordinate, and $26 \%$ claimed they had no responsibilities for age management in the organization. The respondents' ages and responses to the attitudes and belief variables are displayed in Table 1.

Seven factors with eigenvalue greater than 1.0 appeared through factor analyses of the 20 items probing for 'measures' to promote senior workforce participation in working life, accounting for $63.1 \%$ of the total variance. The factor structure is displayed in Table 2. Factor I - Esteem and enrichment - was constituted by increasing appreciation, offering more access to interesting tasks and learning opportunities, adding decision latitudes and additional responsibilities, and offering a role as a specialist and mentoring of younger workforce members. Factor II - Wages and bonuses - contained increased wages, bonuses, and increased pensions as a consequence of extending careers. Factor III - Working hours - was made up by reducing the seniors' daily working hours while maintaining full wages, combining paid part-time work and pension, and offering extra holidays dependent on an extended working career. Factor IV - Workload - was composed of two items, i.e., reducing senior physical and psychological workloads dependent on an extended working career. Factor V - Repositioning - contained offering a different position and/or different work content dependent on an extended working career. Factor VI - Responsibilities - carried the idea of reducing the responsibilities of 
Table I Predictor variables: measures, standard deviations, and minimum and maximum values $(n=660)$.

\begin{tabular}{lcccc}
\hline Variable name & Mean & St. dev. & Min & Max \\
\hline Employees' attitudes make it easy to redesign tasks to fit senior workers & 3.1 I & 0.65 & । & 4 \\
\hline I think it is important to work with age management actions & 3.30 & 0.5 | & | & 4 \\
\hline I think there is too much focus on age management actions & 1.80 & 0.63 & | & 4 \\
\hline To what extent can the employer prevent early exits & 2.92 & 0.65 & | & 4 \\
\hline $\begin{array}{l}\text { To what extent would the respondent prefer early retirement when } \\
\text { reaching 62 }\end{array}$ & 2.22 & I.00 & | & 4 \\
\hline $\begin{array}{l}\text { To what extent would the respondent prefer to continue working } \\
\text { beyond the age of 62 with reduced workload? }\end{array}$ & 2.73 & 0.96 & | & 4 \\
\hline Respondent's own age & 51.5 & 8.32 & 28 & 69 \\
\hline At what age do employees become 'older workers'? & 56.49 & 4.90 & 25 & 70 \\
\hline
\end{tabular}

the senior workers. Factor VII - Pensions - included reducing pensions for early retirement and increasing pensions for extended working careers.

Sum scores were created from the structure of these factors. The Increasing esteem and enrichment sum score contained all eight items loading on the corresponding factor with an alpha $=0.84$. For the second sum score, the Increasing wages and bonuses sum score, the number of items was reduced from three to two items, omitting 'Offer higher pensions dependent on an extended working career,' to increase the alpha coefficient to 0.73. Similarly, the Reducing working hours sum score attained an alpha $=0.58$ when omitting the third item, 'Offer extra holidays dependent on an extended working career.' The Reducing workload sum score contained only two items with an alpha of 0.65 . The Repositioning sum score also contained two items and reached an alpha $=0.65$. However, for the sum scores for factor VI Responsibilities and factor VII Wages and bonuses, the alpha coefficients were 0.11 and 0.28 , respectively, and therefore these sum scores were discarded from further analyses.

Mean values along with $95 \%$ confidence intervals for the five sum scores are shown in Figure 1. All sum scores had a maximum value of 4.0, but varied in minimum values according to their ranges. Reducing working hours was the 'measure' receiving the highest average ratings and displaying the most narrow range of responses (minimum value of 2.5); it also appears as the 'measure' on which the managers could most easily agree as an adequate 'measure' to expand senior workers careers, and thus as an age management strategy. The Reducing working hours mean sum score was significantly higher than all other mean sum scores in these analyses. The second most important 'measures' of extending workers' careers were the Reducing workload and the Increasing wages and bonuses 'measure.' Although ranked significantly lower than the Reducing working hours 'measure,' there were no significant differences between the mean sum scores of the two, and they also had the same range with minimum values equal to 1.5 , representing less inter-individual agreement among managers as compared with the Reducing working hours 'measure.' Furthermore, significantly lower ranked was the Increasing 
Table 2 Factor structure of 'measures' variables. Principal Component Analysis. Varimax with Kaiser Normalization. Amount of variance explained by factors $=63.1(n=660)$.

\begin{tabular}{|c|c|c|c|c|c|c|c|}
\hline Factors Variables & I & $\|$ & III & IV & $\vee$ & VI & VII \\
\hline $\begin{array}{l}\text { Increasing managers' and co-workers' appre- } \\
\text { ciation and encouragement }\end{array}$ & 0.76 & & & & & & \\
\hline New and interesting tasks & 0.75 & & & & & & \\
\hline Increasing task variety & 0.75 & & & & & & \\
\hline Increasing learning opportunities & 0.72 & & & & & & \\
\hline Increasing decision latitudes/control & 0.70 & & & & & & \\
\hline Mentoring younger colleagues & 0.67 & & & & & & \\
\hline Increasing responsibilities & 0.59 & & & & & & \\
\hline Specialist role & 0.51 & & & & & & \\
\hline Increasing senior workforce wages & & 0.85 & & & & & \\
\hline Offering bonuses for work after 62 & & 0.85 & & & & & \\
\hline $\begin{array}{l}\text { Offering higher pensions dependent on an } \\
\text { extended working career }\end{array}$ & & 0.46 & & & & & \\
\hline
\end{tabular}

Reducing seniors' daily working hours while $\quad 0.80$

maintaining full wages

\begin{tabular}{ll}
\hline Combining paid part-time work and pension & 0.79 \\
\hline $\begin{array}{l}\text { Offer extra holidays dependent on an } \\
\text { extended working career }\end{array}$ & 0.51 \\
\hline
\end{tabular}

\begin{tabular}{ll}
\hline Reducing senior physical workload dependent & 0.83
\end{tabular}

on an extended working career

$\begin{array}{ll}\text { Reducing senior psychological workload de- } & 0.77\end{array}$ pendent on an extended working career

$\begin{array}{ll}\text { Offering a different position dependent on an } & 0.83\end{array}$ extended working career

Offering different work content dependent on 0.80 an extended working career

Offering reduced responsibilities dependent on an extended working career

Offering increased responsibilities dependent $-0.32$ on an extended working career

Offering stable reduced pensions dependent on early retirement

Offering stable increased pensions dependent on an extended working career

\begin{tabular}{lccccccc}
\hline Eigenvalue & 4.4 & 2.0 & 1.7 & 1.2 & 1.1 & 1.1 & 1.0 \\
\hline$\%$ of variance explained by this factor & 19 & 9 & 8 & 8 & 8 & 6 & 6 \\
\hline
\end{tabular}


esteem and enrichment 'measure,' and the same range of responses was found for this sum score. Finally, Repositioning was perceived as the least effective alternative, showing a significantly lower mean value than all the others 'measures' and also representing a minimum value of 1.0 as an indication of lack of agreement among managers as to the sufficiency of this measure.

Few of the structural-, organizational-, and individual-level variables included in the multiple regression analyses influenced the measures to extend senior workforce career sum scores (Table 3). None of the structural-level variables were significantly related to the dependent variables, indicating that there were no differences among county-,

Table 3 Predicting measures to extend senior workforce careers (sum scores) from structural-, organizational-, and individual-level variables. Multiple regression analyses $(n=660)$.

Variable list (predictors)

Beta Coefficient

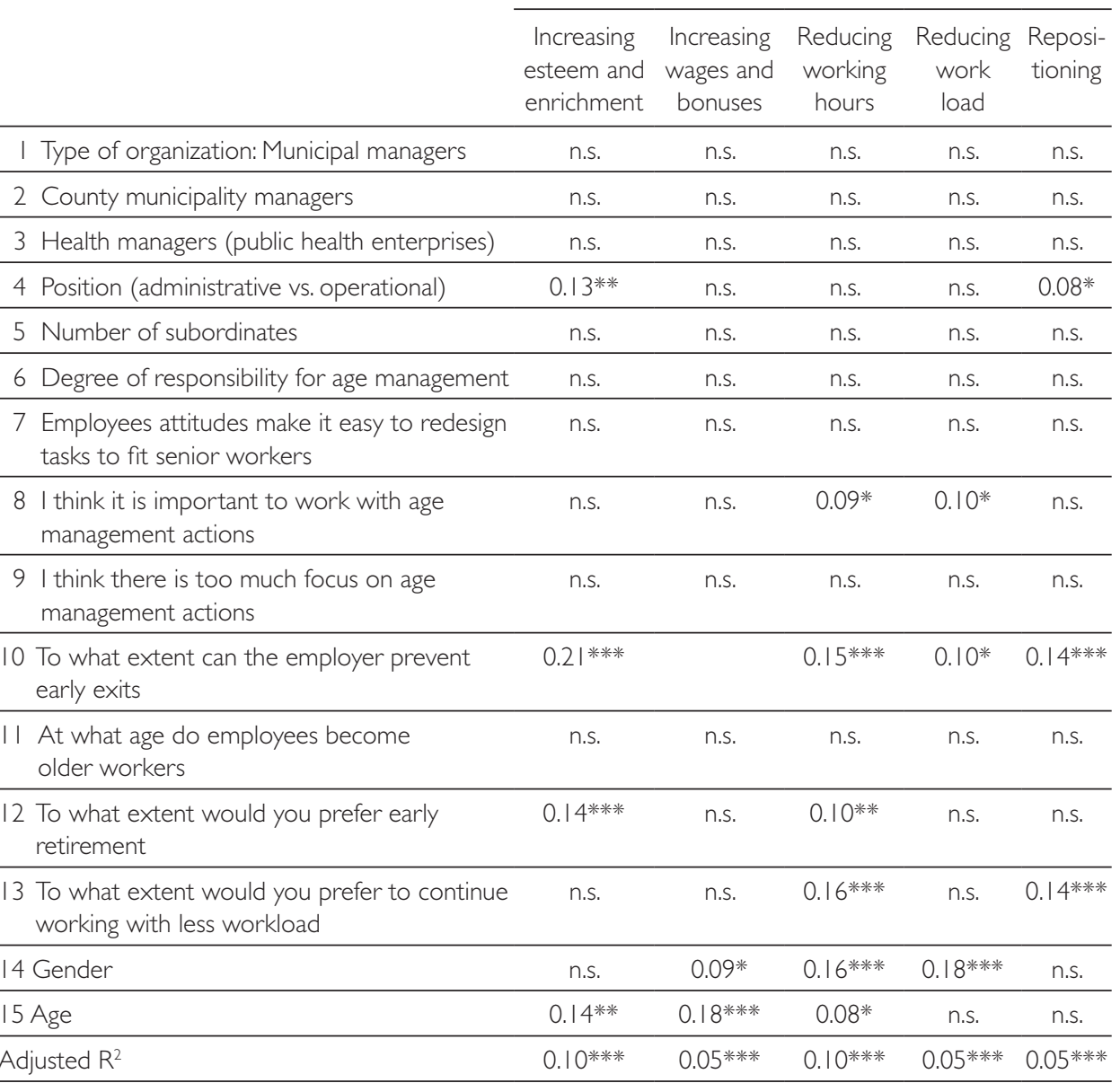

* Significant on a 0.05 level of significance

** Significant on a 0.01 level of significance

**** Significant on a 0.001 level of significance 
municipal-, and health institution-level managers' responses. On the organizational level, only the Position variable had effect, indicating that the lower management levels gave stronger support to Increasing esteem and enrichment and Repositioning. The managers' own attitudes and beliefs were more important in understanding the variability of the senior workforces' extended working careers' sum scores. The belief that the organization can prevent early exits predicted Increasing esteem and enrichment, Reducing working hours, Reducing workload, and Repositioning. The attitude of finding senior career issues important was positively related to Reducing working hours and Reducing workload. The attitude of an individual preferring his/her own early exit predicted Increasing esteem and enrichment and Reducing working hours, thus indicating that managers looking for early exits themselves value these solutions higher. A similar effect was found for the attitude of an individual looking for less workload in relation to Reducing working hours and Repositioning. Managers venting this attitude valued shorter working hours and repositioning as solutions for extending senior workforces' careers. Also, gender and age were of some importance. Female managers valued the solutions of Increasing wages and bonuses, Reducing working hours, and Reducing workload more than their male counterparts did. Finally, the higher the managers' ages, the more they valued the strategies of Increasing esteem and enrichment, Increasing wages and bonuses, and Reducing working hours. The effects were small as observed by the standardized beta coefficients, and the amount of variance explained in the five sum scores was quite small.

\section{Discussion and conclusions}

Public sector managers believe in at least seven different measures to extend senior careers. Ranked according to their importance, they include Reducing working hours; Reducing workload; Increasing wages and bonuses; Increasing the esteem and enrichment of work; and finally Repositioning of the workforce. Also relevant are Reducing responsibilities and Reducing pensions. The latter two were not included in the final analyses due to low internal consistency of these variables when calculated as sum scores.

It should be noted that $26 \%$ of the managers claim to have no responsibility for organizational senior policies. It is argued here that this may be a sign of a 'Laissez-faire' leadership approach: As long as they are not called upon by anybody higher ranked in the organizational structures, they simply do not intervene or even care. They may also disagree with the organizational strategies and be negative toward employing older workers. This conclusion relies upon the fact that holding an organizational leadership position automatically includes responsibility in accordance with the central organizational strategies and agreements. If an organization, as those included in this study, has signed the Norwegian Three-partite Agreement on Including Working Life, none of its managers may claim to not be responsible for practices supporting this organizational obligation. Alternatively, they might not have been instructed about the agreement and its implications; however, that is less likely as the managerial line, the occupational health services, and the unions' representatives have been involved in signing the agreement; thus, it is hard to claim that lack of information is the reason for the findings observed here. 
Fitting jobs to the senior workforce capacities dominate managers' ways of thinking, reflecting the 'Age Management Model' as a way to conduct age management. Foremost, managers believe in adapting working hours to the needs and capabilities of the senior workforce as the main strategy to extend their careers. Also, reducing the workload seems to attract the thinking of the managers as a way of meeting these challenges. This approach is feasible if the production system allows such age- and capacity-related differentiation of workloads, and it should be expected to lead to less fatigue and more willingness to extend the working career. It probably requires a good dialogue between the worker and the manger where trust and insight are in place, and it works for about a third of the workforce in the Vattenfall case (Mykletun and Furunes 2011). Moreover, the approach must rely upon a shared understanding of organizational social justice (Skarlicki and Folger 2003), where those most in demand for reduced workload enjoy the acceptance from the rest of the workforce for this solution. Such social acceptance of special agreements for older workers is a part of the managers' decision latitude or rooms to maneuver (Furunes et al. 2011). Solem and Mykletun (2009) show that 15\% of the workers themselves find more holidays and reduction in working hours and $14 \%$ lessened workload, to be a good motivator when considering the issue of retirement. Another $12 \%$ were concerned about their health as a prerequisite for extended work careers, and $5 \%$ argued for improvements at the workplace as the decisive factor.

The findings also show that managers regard the time and energy of the senior workforce as being 'for sale,' reflecting the 'Market Model.' This could be expected, since several municipalities have claimed to have succeeded when using this model as a way of extending senior careers and of saving pension costs. Obviously, the possibility to earn an extra bonus and increased payment in the final years of a career is attractive to the individual worker, perhaps particularly if they are waiting for a spouse to retire within a number of years. Solem and Mykletun (2009) show that 29\% of the Norwegian workforce mention economical rewards as the most important driver for prolonged work careers, far beyond others like working conditions, leadership, and work content. If combined with the Age Management Model, one could propose that those in need for easier work would receive a shortening of hours or workload, while those driven by economical rewards could ask for increased pay or bonuses. This would require quite flexible organizational age management strategies and measures, and also this approach would require a trustful and considerate relationship between leaders and subordinates. The practice of this model could also be extended by allowing the manager to make such reward agreements only with the especially needed or efficient workforce. An individual's own health and a good quality of the working environment probably add to the list of factors that should be considered; however, there is a lack of research on how this model works from the workers' points of view. This latter argument applies to the other models as well.

Also, the third way of thinking, i.e., the 'Human Relations' perspective, is reflected in the findings, though it is not as highly esteemed as the Market Model and the Age Management Model. This school of thought is less targeted than the other two; however, it conveys advantages like learning opportunities and other assets that are likely to enhance the esteem of the workers and improve their job satisfaction. The model implies competence development and good workplace dialogue and emphasizes on improvements of the quality of working life. One could wish for a higher rating for this model, as it would improve the working environment in general and especially for those it would 
be applied to. The workforce ranked 'interesting work' and 'work content' as third in priority if being motivated to prolong their work career, representing about $12 \%$ of the responses (Solem and Mykletun 2009).

It appears that the public sector managers believe in the possibilities of applying different strategies to individual workers to meet their demands for uniquely adapted work organization and environment. This fits well with the outcomes from research on 'retention management' and with basic ideas in 'diversity management.' Nevertheless, one should be aware of the potential conflicts in breaking the principles of organizational justice, especially those that relate to distributive justice, which deals with the ways the outcomes of decisions are perceived (Skarlicki and Folger 2003). More research should focus on conditions that facilitate acceptance of this deliberate type of organizational injustice.

Managers' beliefs do not vary across public service sectors (structural factors). Organizational-level variables play a modest role in explaining variance in the 'measures' variables. Compared with top managers, middle (operational) managers hold stronger beliefs in the value of Increasing esteem/enrichment and Repositioning. Apart from this, organizational-level factors are not important as predictors in this study.

Managers' attitudes predict how they value various measures: a general belief in the importance of senior policies and trust in the possibilities that age management achievements can succeed relate to the 'measures' scores. Also, managers' own senior career plans influence their evaluations of measures to extend the senior careers of their workforces. Planning their own early retirement and their own workload reductions predicts less trust in measures to extend senior careers of their workforces.

Finally, the managers' age and gender influence their beliefs in measures to extend the careers of their senior workforce. Female managers and senior managers hold the strongest beliefs in such measures.

Only weak predictions were shown for the present models. Further research should address effects of measures to retain senior workers in longitudinal designs where the measures are tested. More research should address possible mechanisms underlying the structures reported here, e.g., by focusing on organizational culture and climate when looking for predictors. For instance, Iverson and Deery (1997) suggest that the hospitality industry has created and reinforced a turnover culture due to its reputation of limited career development and promotional opportunities, whereby acceptance of turnover is a normative belief held by employees. While different 'industries' included in this research are not that different, there might still be internal company cultures that act as underlying factors for employees leaving, often promoting one philosophy while practicing another. Julià et al. (1997) found this in their study of managers in Restaurant Associates, where discrepancy usually lies in salary and opportunities for advancement. Age management strategies for the future could profit from working on organizational cultures, and attitudes and values should still be 'hammered' into the minds of managers because their attitudes may make a difference in the ways of perceiving to extend senior careers. Empowerment to practice these measures could be the greater challenge at the end of the day.

A major limitation for generalization from this study is that its context was Norway. Norway has been considered to have a strong economy. Unemployment rates have been low and immigration is needed to keep up the production. Consequently, older workers may be more in demand at work, and retention strategies for this group 
are practiced. With a less heated labor market, the willingness to offer rewards and other measures to prolong older workers' careers will most likely be of less importance to keep up the productivity. New and younger workers wait in line, and the working life is less dependent upon older workers. Hence the above observations and conclusions may not be so relevant for the time being to some other countries. However, projections of demographic changes indicate that the challenges of an ageing workforce will apply to a wide range of nations in the years to come.

\section{References}

Agars, M. D. and Kotke, J. L. (2004) 'Models and Practice of Diversity Management: A historical Review and a Presentation of a New Integration Theory'. In Stockdale, M. S. and Crosby, J. F. (eds) The Psychology and Management of Workplace Diversity. Oxford: Blackwell Publishing, pp. 55-77.

Aviolo, B. J., Bass, B. M. and Jung, D. I. (1995) MLQ - Multifactor Leadership Questionnaire. Technical Report. Redwood City: Mind Garden* Inc.

Bass, B. M. (1990) Bass and Stogdill's Handbook of Leadership Theory, Research and managerial Applications. 3rd ed. New York: The Free Press. A Division of Macmillan, Inc.

Bass, B. M. (1999) 'Two Decades of Research and Development in Transformational Leadership'. European Journal of Work and Organizational Psychology, 8(1): 9-32.

Bell, V. (2003) Retaining the Best Workforce: Sustainable HRM Practices. Stavanger: University of Stavanger (Master of Science Thesis).

Bolman, L. G. and Deal, T. E. (2004) Nytt perspektiv på organisasjon og ledelse: Struktur, sosiale relasjoner, politikk og symboler. (Reframing Organizations. Artistry, Choice, and Leadership). Oslo: Gyldendal Norsk Forlag AS/John Wiley and Sons, Inc.

Brooke, L. (2003) 'Human Resource Costs and Benefits of Maintaining a Mature-Age Workforce'. International Journal of Manpower, 24: 160-183.

Butler, T. and Waldroop, J. (2001) 'Job Sculpturing: The Art of Retaining your Best People'. In Harvard Business Review on Finding and Keeping the Best People. Boston: Harvard Business School Publishing Cooperation, pp. 179-204.

Camarer, C. (2002) Behavioral Game Theory: Experiments on Strategic Interactions. Princeton: NJ: Princeton University Press.

Cappelli, P. (2000) 'Managing Without Commitment'. Organizational Dynamics, 28(4): $11-24$.

Chan, G., Tan, V. and Koh, D. (2000) 'Ageing and Fitness to Work'. Occupational Medicine, 50: 483-491.

Dalen, E. (2011a) Norsk seniorpolitisk barometer 2011. Ledere i arbeidslivet. (Age Management Barometer of Norway 2011. Managers) Oslo: Synnovate Norge/Senter for Seniorpolitikk.

Dalen, E. (2011b) Norsk seniorpolitisk barometer 2011. Yrkesaktiv befolkning. (Age Management Barometer of Norway 2011. Workforce) Oslo: Synnovate Norge/Senter for Seniorpolitikk.

Davies, D. R., Metthews, G., et al. (1991) (eds) Ageing and Work. International Review of Industrial and Organizational Psychology. New York: John Wiley and Sons Ltd.

DeBeauvoir, S. (1976) Ålderdomen (La Vieillesse). Stockholm: Almquist and Wiksell Förlag AB.

Edwards, J. E. and Rode, L. G. (1986) A Path Analytic Approach to the Construct Validation of Selected Leadership Scales. Chicago: Academy of Management.

Featherstone, M. and Wernick, A. (1995) Images of Aging: Cultural Representations of Later Life. London: Routledge. 
Flynn, G. (1994) 'Attracting the Right Employees - and Keeping Them'. Personnel Journal, 73(12): 44-49.

Forsberg, H. (2001) Attitudes toward Turnover in the Hotel Industry: An Experimental Intervention Study of Norwegian Hotel Managers. Stavanger: University of Stavanger (Master of Science Thesis).

Forte, C. S. and Hansvick, C. L. (1999) 'Applicant Age as a Subjective Employability Factor: A Study of Workers over and under Age Fifty'. Journal of Employment Counselling, 36: 24-34.

Friedman, B., Hatch, J. and Walker, D. M. (1998) Delivering on the Promise. How to Attract, Manage, and Retain Human Capital. New York: The Free Press. A Division of Simon and Schuster Inc.

Furuberg, J., Grambo, A. C. and Åretun, T. (2008) Arbeidsmarkedet fram mot 2030. (The labour market towards yar 2030) Oslo: Statistisk sentralbyrå (Statistics Norway).

Furunes, T. and Mykletun, R. J. (2005) 'Age Management in Norwegian Hospitality Businesses'. Scandinavian Journal of Hospitality and Tourism, 5: 116-134.

Furunes, T. and Mykletun, R. J. (2011) 'Do Managers' Perceptions Coincide with Established Stereotyping of Older Workers' Capabilities'. In E. L. Simon (ed) Psychology of Stereotypes. New York: Nova Science Publishers, Inc., pp. 173-192.

Furunes, T., Mykletun, R. J. and Solem, P. E. (2011) 'Age Management in the Public Sector: Managers' Decision Latitude'. International Journal of Human Resource Management, 22(6): 1232-1247.

Gould-Williams, J. (2004) 'The Effects of "High Commitment” HRM Practices on Employee Attitude: The Views of Public Sector Workers'. Public Administration, 82: 63-81.

Griffeth, R. W., Hom, P. W. and Gaertner, S. (2000) 'A Meta-Analysis of Antecedents and Correlates of Employee Turnover: Update, Moderator Tests, and Research Implications for the Next Millennium'. Journal of Management, 26(3): 463-488.

Hays-Thomas, R. (2004) 'Why now? The Contemporary Focus on Managing Diversity'. In Stockdale, M. S. and Crosby, J. F. (eds) The Psychology and Management of Workplace Diversity. Oxford: Blackwell Publishing, pp. 3-30.

Hilsen, A. I. and Salomon, R. (2010) Seniorpolitikk - virker virkemidlene? (Age management - are management means effective?) Oslo: Arbeidsforskningsinstituttet/Work Research Institute, AFI-rapport 4/2010.

Hom, P. W. and Kinicki, A. J. (2001) 'Toward a Greater Understanding of How Dissatisfaction Drives Employee Turnover'. Academy of Management Journal, 44(5): 975-987.

Hoviskeland, T., Holm, E. D., Neumann, I. B., and Overland, E. F. (eds) (2001) Norway 2030 - Five Scenarios about the Future of the Public Sector. Oslo: JW Cappelens Forlag.

Ilmarinen, J. (2001) ‘Aging Workers’. Occupational Medicine, 58: 546-552.

Ilmarinen, J. (2002) 'Promotion of Work Ability during Aging'. In Kumashiro, M. (ed) Aging and Work. New York: Taylor and Francis Group, pp. 21-35.

Iverson, R. D. and Deery, M. (1997) 'Turnover Culture in the Hospitality Industry'. Human Resource Management Journal, 7(4): 71-82.

Johnston, W. B. and Packer, A. H. (1987) Workforce 2000. Indianapolis, IN: Hudson Institute.

Julià, M., Navarrete, G. and Samson, S. (1997) Restaurant Associates. Analysis of Turnover Costs, Ithaca, N. Y.: Cornell University, School of Hotel Administration.

Kilbom, A., Westerholm, P., Hallsten, L. and Furåker, B. (1997) (eds). Work After 45? Arbete och Hälsa Vetenskapelig skriftserie: 29. Solna: Arbeidslivsinstitutet.

Laflamme, L. and Menkel, E. (1995) 'Aging and occupational accidents. A review of the literature of the last three decades'. Safety Science, 21: 145-161.

Leopold, J., Harris, L. and Watson, T. (2005) The Strategic Managing of Human Resources. Harlow, England: Prentice Hall. 
Lewin, K. and Lippit, R. (1938) 'An Experimental Approach to the Study of Autocracy and Democracy: A Preliminary Note'. Sociometry, 1: 292-300.

McFillen, J. M., Riegel, C. D. and Enz, C. A. (1986) 'Why Restaurant Managers Quit (and How to Keep Them)'. The Cornell H.R.A. Quarterly, 27(3): 36-43.

Mykletun, A., Øverland, S., Dahl, A. A., Krokstad, S., Bjerkeset, O., Glozier, N., Aarø, L. E. and Prince, M. (2006) 'A Population-based Cohort Study of the Effect of Common Mental Disorder on Disability Pension Awards'. American Journal of Psychiatry, 163(8): 1412-1418.

Mykletun, A., Solem, P. E. and Mykletun, R. J. (2000). Alder og arbeid i kommunesektoren. Ansattes planer om tidlig avgang til pension og uføretrygd. (Age and Work in the Municipality Sector: Employees' Plans on Early Retirement on Age and Disability pensions) Oslo: KLP rapport/Stavanger: Høgskolen i Stavanger, Avd. Norsk hotellhøgskole.

Mykletun, R. J. and Furunes, T. (2011) 'The Ageing Workforce Management Programme in Vattenfall AB Nordic, Sweden: Final Report'. In Ennals, R. and Salomon. R. (eds) Older Workers in a Sustainable Society. Great Needs and Great Potentials. Labour, Education and Society Series. Frankfurt am Main: Peter Lang Verlag, pp. 93-106.

NOU (2011: 1) 'Bedre rustet mot finanskriser. Finansutvalgets utredning' (Being Prepared for Finance Crises. White Paper from the Governmental Committee of Finances) Oslo: Departementenes servicesenter (The Document Service of the Ministries).

Pettersen, I. J. (2001) 'Hesitation and Rapid Action: the new Public Management Reforms in the Norwegian Hospital Sector'. Scandinavian Journal of Management, 17: 19-39.

Price, L. (1994) 'Poor Personnel Practice in the Hotel and Catering Industry: Does it Matter?' Human Resource Management Journal, 4(4): 44-62.

Rowley, G. and Purcell, K. (2001) “'As Cooks Go, She Went”: is Labour Churn Inevitable?' International Journal of Hospitality Management, 20(2): 163-185.

Skarlicki, D. and Folger, R. (2003) 'Fairness and Human Resource Management'. Human Resource Management Review, 13(1): 1-11.

Solem, P. E. (2012) '(Possible) Effects of the Financial Crisis on Managers' Attitudes to Older Workers'. Nordic Journal of Working Life Studies, 2(2): (submitted)

Solem, P. E. and Mykletun, R. J. (2009) Endringer for seniorer i arbeidslivet fra 2003 til 2008. (Changes in Working Life for Older Workers from 2003 to 2008). Oslo: NOVA. NOVArapport 20/09.

Stern, H. L. and Miklos, S. M. (1995) 'The Aging Worker in a Changing Environment: Organizational Issues'. Journal of Vocational Behaviour, 47: 248-268.

Sturman, M. C. and Trevor, C. O. (2001) 'The Implications of Linking the Dynamic Performance and Turnover Literatures'. Journal of Applied Psychology, 86(4): 684-696.

Taylor, P. and Walker, A. (1998) 'Employers and Older Workers: Attitudes and Employment Practices'. Aging and Society, 18: 641-658.

Tikkanen, T. (1999) Education and Training for Older Workers. Paper presented at the Active Strategies for an Ageing Workforce, 12-13 August 1999. Turku, Finland.

Torrington, D. and Hall, L. (1998) Human Resource Management. 4th ed. London: Prentice Hall Europe.

Tuomi, K., Ilmarinen, J., Seitsamo, J., Martikainen, R. and Aalto, L. (1999) 'Work, Life-style, Health and Work Ability among Ageing Municipal Workers in 1981-1992'. In Kirjassa, M., Ilmarinen, J. and Louhevaara, V. (eds) FinnAge-Respect for the Ageing. Helsinki: Finnish Institute of Occupational Health. Report 26, pp. 220-233.

Wasmuth, W. J. and Davis, S. W. (1983) 'Managing Employee Turnover: Why Employees Leave'. The Cornell H.R.A Quarterly, 24(1): 10-18. 